\title{
Can China overcome the Difficulties of Establishing Successful Global Brands?
}

Dr David Floyd, Dr Barry Ardley, \& Dr J ohn McManus Lincoln Business School, Lincoln University, United Kingdom 


\section{Abstract}

It is clear to most observers that China is taking an increasing role in world trade not only through political interventions but as a result of its strategy regarding acquisitions. There have been a significant number of these recently, some of which like the Rover take over in the UK and more recently Geely taking over Volvo, have been high profile. This paper provides a brief overview of these developments. It is then argued that an important issue facing the Chinese companies involved in these take overs is one of brand equity and country of origin effects. This issue is of equal importance to China's global competitors as well. A review of the literature shows that consumer perception constructs, such as perceived quality, have been well researched through numerous country-of-origin papers. A key issue to explore here however, is the extent to which the new nationality of brand ownership will have an impact on consumer perception constructs of brand equity. This paper discusses these two areas and examines their relationship in conceptual terms. A research agenda is then suggested, which forms the basis of a proposed interpretative project aimed at establishing the views of consumers regarding the phenomenon of well known brands being taken over by a new country of origin - evidence from the car industry draws on the progress being made in this area. The research aims to examine the implications for consumer based valuations of brand equity and the types of new strategic thinking this could engender. It is argued that the Chinese brand lacks the main components for global success in several areas though in time these factors will be addressed. .In the short term more focus will be made on supplying the local Chinese market though experienced gained from increased exports of components and collaboration in research from abroad as shown in the examples of the car industry will help strengthen the reputation of Chinese products in the longer term as well as helping to establish more Chinese global brands.

Key Words; country of origin - brand equity - qualitative - strategy 


\section{INTRODUCTION: CHINA AND BRAND OWNERSHIP}

The purpose of the opening sections of this paper is to examine in broad conceptual terms the implications of the growing role of China in international marketing and then to suggest an area where some fruitful future research could take place. Fan (2005) has pointed out that China is the world's factory, a place where many products in everyday use are made and where, until quite recently, little has been seen of a developing home based industry. Significantly, China, as a place where manufacturing has been growing steadily, has not created a single brand that is recognized worldwide. Yet, despite this, China has become quite recently the owner of several worldwide recognized brands. This is a result of a few major mergers \& acquisitions in the last couple of years (Fan 2005). An important example includes TCL Thomson Electronics. This is a new company created after the merger of TCL and Thomson with $65 \%$ owned by TCL, where the latter obtained the famous electronic brands such as Thomson, RCA and Alcatel. We can add further examples. There is the Chinese computer maker Lenovo, who acquired IBM's global PC business for US $\$ 1.25$ billion in cash and shares and carmakers Nanj ing Automotive who during last year acquired Rover's assets. In time these may become global brands similar to development in Korea where brands such as Samsung have now become common place. Similar developments took place in J apan with the establishing of Sony and Toyota. The potential in China is huge as Price becomes less important as Chinese consumers experience increased wealth in the years to come. However many barriers need to be overcome, markets need to be further internationalised and competition needs to be encouraged. In marketing terms, there is likely to be implications here for consumer views of brand equity as result of new ownership and perhaps subsequent changes to purchasing decisions.

In virtually all cases here smaller overseas companies have bought off the bigger and more well established ones, which means that a range of famous brands and iconic symbols like Thomson, RCA, Schneider, IBM, Rover, MG and even Austin, are all now owned by companies from a different country. China, comparatively speaking, has a very different culture and no history of association with these brands before the mergers and acquisitions occurred. 
How will consumers see this? What sorts of impact could we expect to see in terms of consumer behaviour? To what extent will brand equity come to be dominated by consumer's cultural views regarding product origins? These and other questions could become increasingly important. All the abovementioned western brands are now to be produced and assembled in China. Research and development may well occur in both China and Europe. The key point is that these brands are now Chinese owned and this could just be the start of a burgeoning strategy (McManus et al, 2007). These well-known brands will certainly provide a platform for the globalization of a range of Chinese companies, while also presenting them with a unique set of business challenges.

Crucially, will the brand equity of these established products be sustained or improved, diluted or even damaged under the name of new ownership? This is not a phenomenon that a concept of country of origin (COO) or even countryof-origin of brand (COB) can explain very well. COO only refers to the place where the products were made or assembled and COB is usually defined as the country to which a brand is perceived to belong to, by its target consumers (Schaefer 1997). Clearly, country of origin effects and brands are significant factors which determine an organisations international competitiveness. It is argued here that country of origin and brand equity will need to be researched together if a real in depth understanding of the new nationality of brand ownership is likely to be achieved. This provides the key area that the proposed research seeks to examine.

\section{COUNTRY OF ORIGIN, BRAND EQUITY AND CONSUMER PERCEPTIONS}

In step with the increasing amount of global expansion strategies by firms around the world, a large amount of literature has been developed which considers the impact of country of origin labels on consumer product evaluations. A large number of factors have been examined in the COO literature. An example is Sharma et al (1995). The latter have developed a model which tests antecedents and moderators of consumer ethnocenricism. Schooler (1965) and Reierson (1966; 1967) initiated the stream of work on COO with the prime purpose of determining whether or not a country of origin 
effect existed in the first place. According to Al-Sulaiti and Baker (1998), COO effects remain the most researched among the many factors believed to influence consumer brand knowledge in an age of international competition. Further research shows that COO effects of a product have been found to influence consumer evaluations of the product on two key dimensions, these being perceptions of quality (Khachaturian and Morganosky, 1990), and perceptions of purchase value (Ahmed and d'Astou, 1993). Allied to this, several researchers have attempted to explain the psychological process of COO effects through the summary construct model, the halo effect model, and the cognitive elaboration model (e.g. Han 1989; Hong and Wyer 1989; Knight and Calantone 2000).

It seems clear that country of origin effects cannot be explained exclusively by focusing on issues of product quality. It is argued that country of origin factors, allied to brand equity, can also be about strong emotional connotations. This may be particularly pronounced in terms of Chinese brands, from the point of view of UK consumers. What can be seriously questioned is the notion that country of origin effects is no longer important. It is unlikely that consumers hold neutral or equivocal views about China and the East. Culturally conditioned factors are likely to impact on consumer perceptions of the brand and the company which has been taken over. In addition, it is proposed that consumer perceptions of this factor are likely to be very significant in terms of the future success of the brands which Chinese companies acquire. Those who question, probably mistakenly, the importance of COO effects include J ohansson (1989) and Phau and Prendergast (1998). Their argument is that the origin of manufacture is no longer significant to buying behaviour in the age of globalization. It probably can be shown however that consumers are still very much ethnocentric. The reality might be that an increasing awareness of the global condition actually means localisation and identity become more important. For localisation, this might not just mean a country, but also perhaps a trading bloc as well.

With regard to brand equity, there have been numerous approaches to its measurement and estimation since the term emerged in the 1980s. Both 
academics and practitioners have been concerned with definitional issues, with an added emphasise on accurate measurement, in order to assist managers with guidance on ways to enhance or build strategic success. Aaker (1991) is one of the few authors to incorporate both attitudinal and behavioural dimensions from the perspective of the consumer. In his definition, he suggested five key components of brand equity. These consist of consumer perception, awareness, associations and perceived quality and also consumer behaviour constructs such as loyalty and willingness to pay a price differential. Brands send messages in terms of reliability, image and value for money according to Milman 2007. Most authors provide definitions of brand equity that are generally similar to Farqubar's (1989) definition of equity. This is expressed as the value added by the brand to the product. The work of Srinivasan (1979), Aaker, (1991) Kamakura and Russell (1993) Keller (1993) Simon and Sullivan (1993), all point in this general direction.

Brand equity has in fact been viewed from a variety of perspectives: the investor, the manufacturer, the retailer, or the consumer (Aaker 1991; Farquhar 1989; Srivastava and Shocker 1991; Tauber 1998). It is argued here that a clear link exists between country of origin perceptions held by consumers and brand equity. To date, this link has not been explored in relation to the changing basis of ownership from Western companies and brands to Chinese companies. Clearly, brand equity is important as manufacturers and retailers are motivated by the strategic implications it entails (Keller 1993). Brand equity is of interest to managers because of brand loyalty and brand extensions. We can now add to this country of origin effects. Thakor \& Kohli (1996), point out that the difficulties of global competition have underscored the importance of established brands in consumer markets and as a consequence, how consumers value brands in an international context is central to marketing success. Brands must have meaning to the consumer. In other words, there is no value to the investor, the manufacturer, and the retailer if there is no value to the consumer (Farquhar 1989). Customer-based brand equity refers to the differential effect of brand knowledge on consumer response to the marketing of the brand as pointed out by Kamakura and Russell (1991) and Keller (1993). Thus brand 
equity is conceptualized from the perspective of individual consumer and customer-based brand equity occurs when the consumer is familiar with the brand and holds some favourable, strong and unique brand associations in the memory (Kamakura and Russell 1991). Apart from brand knowledge Keller (1993) also emphasises that there are two other important concepts of the customer-based brand equity definition. There is the differential effect and consumer response, both of which are defined to in terms of consumer preferences and loyalty. Thus, it is important to understand how brand value is created in the mind of the consumer and how it translates into choice behaviour.

\section{CONCEPTUALISING THE RELATIONSHIP BETWEEN BRAND EQUITY AND COUNTRY OF ORIGIN: AN OUTLINE RESEARCH AGENDA}

The focus so far in much of the research into country of origin effects has been seen from the perspective of developed countries (Hamin and Elliott (2005). The research suggested here could help to redress this balance. China can be seen to be a developing country and is likely to be so for some considerable time, despite its impressive patterns of growth. In particular, the intention of the proposed research is to find out the impact of $\mathrm{COO}$ of brand ownership on consumers' perceptions and behaviour and the subsequent effect of this on the basis of brand equity. A possible conceptual framework of the impact of ownership of brand on customer-based brand equity is depicted in table 1. This type of framework could provide the starting point for the research which will be based in the United Kingdom. This framework shows an external cue which is the COO of brand ownership, which it is suggested, is likely to have an impact on consumers' perception and behaviour towards a certain brand. These two factors it is argued are likely to have a significant influence on consumer based brand equity. Alden 1999 shows that gaining status is the main factor that needs to be considered in order to create a global brand. It also requires reliability which may have been lacking in some Chinese products.

What needs to be researched is the extent to which the new brand ownership is likely to impact on consumer perceptions, not only of existing brands in 
terms of their equity, but also in respect of possible future brands that Chinese companies may buy up. This new brand ownership is unlikely to impact just on a restricted number of market segments, but could be a phenomenon which extends to a sizeable range of brands and companies in the west. Additionally, it will be necessary to examine the extent to which existing brand equity models are able to deal adequately with the new context of brand ownership, where country of origin may take on increased importance in consumer perceptions. In terms of strategic marketing implications, there may well be important ramifications for the management of brands as what is being experienced, is a new phenomenon of ownership. The research needs to examine at a deep level consumer feelings to country of origin and how this relates to perceptions of brand equity. The possibility exists for the development of new theoretical propositions in a range of brand related areas.

\section{DIMENSIONS OF BRAND STRATEGY}

From the viewpoint of Chinese companies, there exists a major implication here for brand equity management that requires a broader perspective to be taken regarding strategic direction. As a precursory point, it seems clear from the discussion above that Chinese companies operating in worldwide markets will be assessed on the quality of their brands. Superior brands can lead to higher levels of customer satisfaction along with greater perceived value of the services and products offered by the organisation. This can be important for launching new products globally and for facilitating brand extensions (Aaker, 1999), and (Botten and McManus, 1999). Whilst this research has rightfully considered the impact of brands on customer's memories and associations, the influence of branding extends beyond the sphere of consumer perception. When defined as accounting assets (Simon and Sullivan 1993) the economic effects of brands includes specific market valuation factors (Ambler 2003). As a consequence, it is necessary for Chinese companies to consider another dimension of brand strategy decisions, namely the area of financial brand equity. It is essential therefore, that the financial and economic dimensions of the brand also build prominently as a central aspect of a firm's strategy (Botten and McManus, 1999). Incorporating this 
strong financial and economic component to the management of a brand means that Chinese entrepreneurs and marketers can potentially make a significant contribution to the overall strategic success of their organisation. This emphasis on the financial aspects of managed brand equity can be achieved through setting appropriate pricing policies, accomplishing desired product volumes and realising margins. Additionally, marketing in a brand management role can make a viable contribution to the overall business model implementation of Chinese organisations. This can be achieved as the Chinese enterprise seeks to gain advantage in global markets through the processes of defining a value proposition, identifying target customers, developing internal competencies, implementing competitive strategies and from a financial viewpoint, establishing how the venture will make money and develop corresponding growth objectives (Morris et al. 2005). From an economic point of view, brands have no value if the company does not produce an excess profit capable of contributing to existing and future development of assets (Lehmann, 2004; Herremans and Ryans, 1995). The issue for Chinese entrepreneurs is that they must be wary of innovating, or buying and developing brands solely on the basis of image and reputation. The problem might be that they are then unable to convert this type of value into hard profit. Brands are only worth something if a profitable economic formula can be built around them. The implication of this is that is that the Chinese entrepreneur should think in terms of a more unifying definition of brand equity. This definition and implementation process should ideally combine consumer based perceptions of brand equity with financial brand measurement capabilities that systematically examine financial outcomes (Kapferer 2008). These can include factors such as replacement costs, market price, present and future earnings and discounted cash flows (Doyle 2008). In this situation, it is important for Chinese company strategists to work at developing robust marketing metrics in order to measure the brands effectiveness as an intangible asset (Aspara et al 2011; Clark 1999). From this, a sound economic blueprint can be developed for the brand in terms of local and global marketing strategies. Finally, it is worth mentioning that because both culturally and economically there are increasing numbers of Chinese citizens who are shareholders (Gittings 2006), it is more important 
than ever to demonstrate brand value through clear measurement processes. This is a point consistently made by Doyle (2008) and Ambler (2000; 2003). Out of this valuation process, funds provided by stock markets can be directed by Chinese firms to areas where brand investments to be made. If effective strategies are developed in the areas discussed here by Chinese entrepreneurs, then they will be on the way to establishing successful and profitable global brands. This will then provide a secure revenue stream that will assist them in overcoming some of the problems identified earlier in the paper.

\section{Progress towards establishing a GLOBAL BRAND, the CASE OF CAR INDUSTRY}

According to the South China Morning Post April 2011 China is making progress in developing its car brands by acquisition in some cases as in the case of formulating the Haier brand. Recent acquisition of Volvo by Geely has helped strengthen the brand name in the car industry though even here Geely's strategy is to keep the brands separate and not to sell Geely products to the Western market. The move is more to improve research collaboration. Also the superior Volvo brand can attract a higher price in Western markets by not being exposed to lower cost competition (Botten and McManus, 1999). This restriction on competition may help boost profits for the group though some may argue this is unfair competition and illustrate that the power of brand image forms an element of non price competition according to Wall2010. There is further evidence of regional brands developing in China for example Guangzhou Auto with its Triumpchi brand. There is however much evidence of copying Western products both in name and production concept. Future development could include linking up regional brands once a Chinese global reputation is established. Guanxi, Great Wall and Shanghai Automotive could provide the motivation for this. The UK for example formed a large group called the Rover Group in the 1980s and this helped establish the reputation of the J aguar Brand which was a subsection of Rover Group. There has also been a trend towards regional trade and FDI according to Buckley 2007 therefore one would expect to see progress in the China brand from a regional basis to start with followed by full globalisation of the brand. It has also been shown that government backing and the encouragement of a 
number of large global firms led to the success of J apan in the 1980s according to Floyd1998. J apan entered the global market at a low cost base similar to the present situation of China. Furthermore the global economic downturn may lead to a preference to low cost products which is where the strength of China lies.

\section{CONCLUSION}

\section{CHINA AS A FORCE IN GLOBALISED MARKETS}

British and other western consumers are facing a new business phenomenon as China gears up to take on an increasing role on the world stage. It is of interest to the Chinese owners of the once western companies and brands to know what consumer perceptions are as a result of changed conditions of ownership. In terms of competitive challenges, western companies are likely to want to know how robust the brand equity is of companies which have changed hands. Many barriers still need to be overcome in terms of copyright protection and government regulation despite the more recent open approach to international trade. Research would suggest there is a need to know how consumer perceptions are effected by the new country of orgin of brand ownership and what the implications of this are for marketing managers. Further to this, it will be useful for strategists to know whether or not new variables relating to brand equity and country of origin effects can be discovered. The results could have a significant impact on the future marketing strategies of Western and Eastern companies alike. We are currently on the verge of something very new. China is no longer just a market for the west, but is itself soon to be a major strategic force in world business. The car industry cases have further shown the development taking place in terms of acquisition strategy. It has also been suggested that there may be a role and good opportunity for government in encouraging these brands particularly at a time where Western firms are suffering from the after effects of the financial crisis. Successful policy at this current time may help put Chinese brands further on the map in the longer term. 


\section{RefERENCES}

Aaker, D, A., (1991, \& 1999), Managing brand equity, Free Press, New York Ahmed S, Astous A., (1995) Comparison of Country of origin effects on household and organisational buyers product perceptions. European J ournal of Marketing, Vol 29, No 3, pp35-51

Ambler, T., (2003), Marketing and the Bottom Line, London: Financial Times Ambler, T., (2000), Marketing Metrics, Business Strategy Review, Vol 1, No 2, pp 59-66.

Al-Sulaiti, Khalid I., and Baker, M., J., (1998), Country of origin effects: a literature review, Marketing Intelligence and planning, Vol 16, No3, pp 150-68

Aspara, J ., Tikkanen, H., Pontiskoski E. and J arvensivu, P., (2011), Exploration and exploitation across three resource classes. European J ournal of Marketing, Vol 45, No 4, pp 596-630.

Botten, N. \& McManus, J ., (1999), Competitive Strategies for Service Organisations, Macmillan Press, UK,

Buckley P., The determinants of Chinese FDI, J ournal of International Business Studies Vol 38 No 4, pp

Clark, B. H., (1999), Marketing Performance Measures: History and Interrelationships, J ournal of Marketing Management, Vol 15, No 8, pp 711-732.

Chao, P., (1993), Partitioning country of origin effects: consumer evaluations of a hybrid product, J ournal of International Business Studies, pp 291306.

Doyle, P., (2008), Value-Based Marketing, Chichester, Wiley

Fan, Y., (2005), From Made In China to Brand China, in proceedings of the Academy of Marketing Conference, Dublin, July.

Farquhar, P., H., (1989), Managing brand equity, Marketing Research, No 1, September, pp 24-33.

Floyd, D., (1998), How can Europe improve its competitive position? Teaching Business and Economics, Vol 2, No 1

Gittings, J., (2006), The Changing face of China; from Mao to Market, Oxford University Press 
Hackley, (2003), Doing Research Projects in Marketing Management and Consumer Research, Routledge, London

Han, C.M., and Terpstra, V., (1988), Country of origin effects for uni-national and bi-national products, J ournal of international Business studies, Vol?, No? pp

Hamin Elliott G (2005) Consumer Ethnocentricism and Country of Origin Effects: Indonesian Evidence, in Proceedings of the Academy of Marketing Conference, Dublin, July

Herremans, I., M and Ryans, J. K., (1995), The case for better measurement and reporting of marketing performance, Business Horizons Vol 38, No 5, pp 51-60

Hong, S., and Wyer, R.S., (1989), Effects of country of origin and productattribute information on product evaluation: an information processing perspective. J ournal of Consumer Research, Vol 16, pp175-87

J ohansson, J.K., (1989), Determinants and effects of the use of made in labels, International Marketing Review Vol 6, No 1, pp 47-58.

Kamakura, W.A., and Russell, G.J., (1991), Measuring consumer perceptions of brand quality with scanner data: implications for brand equity. Marketing Science Institute, Report, No 9, pp 1-122

Kapferer J. N., (2008), The new strategic brand management: creating and sustaining brand equity long term, London Kogan Page

Keller, K.L., (1993), Conceptualizing measuring and managing customer-based brand equity. J ournal of Marketing, Vol 57, No 1 pp 1-22

Khachaturian, J.L., and Morganosky, M.A., (1990), Quality Perceptions by

Country of Origin, International J ournal of Retail and Distribution Management, Vol 18, No 5, pp 21-30.

Knight, G., A. and Calantone, R. J ., (2000), A flexible model of consumer country-of- origin perceptions A cross-cultural investigation, International Marketing Review, Vol 17, No 2, pp 127

Lehmann, D., (2004), The mediating role of new product development in the link between market orientation and organizational performance linking marketing to financial performance and firm value, J ournal of Marketing Vol 68, pp 73-75 
Marshall C., R., (1999), Designing Qualitative Research, London, Sage Publications

McManus, J., Li, M., \& Moitra, D. , (2007), China and India: Opportunities and Threats for the Global Software Industry, Chandos Publishing, Oxford, UK

Morris M., Schindenhutte, M., and Allen, J., (2005), The entrepreneur's business model: towards a unified perspective, J ournal of Business Research, Vol 58, No 6, pp 726-735

Milman C., (2007), Research issues in building brand equity and global brands in the PC market, J ournal of Marketing Management Vol 23, No 1, pp

Phau, I., and Prendergast, G., (1998), Will country of origin be relegated to obscurity in the global reality?, In Globalisation of business conference, Gazimagusa, North Cyprus, November

Reierson, C., (1966), Are foreign products seen as national stereotypes?, J ournal of Retailing Vol42, pp 33-40.

Schaefer, A., (1997), Do demographics have an impact on country of orgin effects. J ournal of Marketing Management, Vol 13, No 8, pp 813 - 829

Schooler, R., D. (1965), Product bias in the Central American common market, J ournal of Marketing Research, Vol II, pp 394-7.

Simon C. J, and Sullivan M. W., The measurement and determinants of brand equity; a financial approach, Marketing Science Vol 12, No 1, pp 28-52

South China Morning Post April 2011 Special issue on the Shanghai Motor Show

Thakor, M.V., and Kohli, C.S., (1996), Brand origin: conceptualisation and review, Journal of Consumer Marketing, Vol 13, No 3, pp 27-42

Thompson C., J., Locander W., B., Polloi, H. (1989), Putting Consumer Experience Back into Consumer Research: The Philosophy and Method of Existential Phenomenology, J ournal of Consumer Research, Vol 16, pp 133-45

Wall, A., (2010), Applied Economics, Routledge, London 